\title{
Does Privatization Impinge Price Levels?
}

\author{
Muhammad Shujaat Mubarik \\ Asim Mumtaz
}

\begin{abstract}
In the last few decades the transformation of ownership rights of state owned enterprises (SOEs) to private sector, the privatization, is being considered as an important craft to reduce fiscal deficits, increase organizational efficiency, and to control macroeconomic barometers. In Pakistan, especially after 1988, most of the governments have adopted the privatization as mainstay artifice to reduce fiscal imbalances, augment organizational competence and bring macroeconomic stability. The favorable fiscal impact of privatization has been expected from the sale proceeds being used to retire national debt, as well as elimination of losses of the public sector units as these losses are financed from the budget. It is also considered important to foster competition, strengthen capital markets and to encourage foreign direct investment. Since privatization is an exercise with multifaceted implications, many of the studies have been made to evaluate its diversified impacts. But most of the researches carried out have explored its affects on fiscal shortfalls, organizational efficiency and economic growth. Only a few studies have been conducted to see its impacts on economic development, especially on inflation, the single most important macroeconomic indicator which can destabilize the life of masses substantially, if not completely. This research article attempts to highlight the influences of privatization on inflationary pressure and its repercussions. It has been argued that privatization accelerates the inflation thus affecting the development negatively. We are making an effort to test the credibility of the fact through scientific tools. Last thirty years data have been taken for analysis purpose. The econometrics model using "Regression Analysis" would be developed to analyze and interpret the data.
\end{abstract}

Keywords: Privatization, fiscal deficit, macroeconomic barometers, inflationary pressure.

\section{Introduction}

Privatization, a method of redeploying assets and functions from the public sector to the private sector, appears to be a factor that could play a serious role in the quest for growth and development. In recent history, privatization has been a part of political policy and has spread to every region of the world. The process of privatization is an effective way to bring about fundamental structural change.

A world-wide era of privatization has been picking up momentum in recent decades, making it a fairly new trend in the sphere of economic policy. Governments pursuing privatization are not only prone to use its proceeds for debt servicing but also have a strong hope for its contribution towards economic growth and development process.

Muhammad Shujaat Mubarik is lecturer at Mohammad Ali Jinnah University, Karachi, shujaatmubarik@gmail.com Asim Mumtaz is doing his M. Phil Economics from AERC, University of Karachi.

Journal of Independent Studies and Research - MSSE

Volume 9

Number 2

\begin{tabular}{l|l} 
July 2011 & 31
\end{tabular} 
The same has been maneuvered by the Pakistan's government while pursing the privatization in the 1990s and early years of this century. Right now the Privatization Commission of Pakistan is devising a policy measure to privatize at least six of the key industries in order to generate funds for the govt, to reduce the debt burden on government, and to increase organizational efficiency. While proponents of the privatization are admiring the policy, the opponents are of the view that it would not only increase the unemployment in the country but it may also be one of the sources of inflation thus affecting living standard of masses negatively. Opponents argue that SOEs are being subsidized by the government and prices of their products are deliberately kept low in order to extend the welfare to the masses. When these firms would be privatized, the subsidies would be eliminated and free market forces tend to elevate their prices thus bring an array of inflation in the country. The SOE's existing in the oligopoly market structure, would have chance to hoard the supply by making cartels which would not only increase the prices of the commodities but also would be a source of underutilization of resources.

The same time capital intensive behavior of private firms would pursue them to conduct massive layoffs and their existence in oligopoly market would allow them to set the prices of their own choices. This would not only bring the unemployment and inflation in the country but would also push down the living standard of the masses of Pakistan.

In order to authenticate these comments and to testify them, first we are developing the theoretical frame of the issue supported by the empirical and theoretical researches. On the basis of it, we would scientifically test their authenticity.

\section{Theoretical Framework}

The theoretical framework behind the idea of privatization is largely dependant on understanding that privatization proceeds are used to finance fiscal deficits, reduce the debt burden on government, and to increases organizational efficiency. On the other hand privatization is a source of inflation, unemployment and living standard.

About government's raising of funds through privatization, Megginson (2005) states that raising money is, quite naturally, a very attractive objective, and most governments hope that privatization will help to develop national capital markets.

But still there is a controversy in the opinion either privatization affects growth positively or not. Harper, Joel T. (2001) has shown some of the evidences from developing countries where privatization has affected negatively to level of growth in the short run. Uchid and Cook (2001) also found a robust partial negative correlation between privatization and economic growth.

Besides the discussion in growth some of the economists say that it is one of the causes of unemployment and inflation. As William L. Megginson (2005) states in his book "The Financial Economics of Privatization" that in launching privatization programs, most governments simply assert as common knowledge that privately owned companies are inherently better managed and more efficient than are state-owned firms. These governments seem not to realize just how controversial these assumptions are within 
the economics profession, especially among theoretical economists. Theorists generally acknowledge that private ownership causes firms to be more profitable and to operate with greater technical efficiency under most industrial structures, particularly in competitive industries. However, there is far less theoretical consensus about the optimality of private ownership in the presence of significant market failures, and about the ability of private companies to pursue socially desirable goals, such as maximizing employment or providing necessary goods and services at a fair price to all citizens. There is also much controversy about whether commercial enterprises should be asked to pursue social objectives or simply to maximize profits, subject to legal constraints. By far the most controversial issue for theorists is whether natural monopolies-defined as industries with continuously increasing economies of scale, such that only a single producer is economically efficient- should be owned by the state or by private owners (subject to state regulation).

Shleifer and Vishny (1994) highlight that SOEs will be inefficient because some of the politicians use SOEs to pursue non-economic objectives for vested interest, such as maintaining excess employment, building factories in politically (but not economically) desirable locations, and pricing outputs at below market clearing prices. And this practice can not be curbed even in fully competitive markets.

Okten and Arin (2001) find that privatized companies switch to more capital-intensive production processes. These new processes significantly reduce per unit costs and prices, and substantially raise labor productivity and overall output. They also document that capacity utilization and investment increase significantly after privatization, while employment declines significantly and capacity increases insignificantly.

Sina Mazdak (2008) highlights that working class struggles are intensifying in Iran as a consequence of privatization. She expounded that privatization has accelerated the level of inflation which is leading to social conflicts.

\section{Model and Methodology}

The purpose of the study is to examine the effect of privatization on inflation, and living standard. Thus, this study uses a regression analysis to estimate the effects of privatization on inflation, unemployment and economic development. Last thirty years data are being taken for analysis

\subsection{Explanation of Variables}

\section{A Privatization:}

Privatization proceeds have been taken to represent the privatization. It is the amount rupees which have been reaped by the govt while selling of SOEs. 


\section{B. Inflation:}

CPI inflation is representing the Inflation data. It can be argued that CPI may not necessarily contain some of the privatized firm's product. But it indirectly affects the level of Inflation. As the privatization of tractors ( e.g. Millat Tractor's case) effects the prices of tractors, which is one of the prime capital used in agriculture sector, so it will indirectly effect the agricultural prices.

\section{Economic Development:}

Previously we took the HDI to represent the Economic Development. But now, on the recommendation of moderators, we have taken Per Capita Income (Purchasing Power Parity)

\section{Unemployment:}

Unemployment rate is just taken by dividing the number of unemployed people over total labor force.

\section{Statistical Models}

$Y=\alpha+\beta X$

We have developed four models by using Simple Linear Regression. In all four models Privatization is independent variables, whereas Inflation, GDP, HDI and unemployment are dependent variable. Following is their structure:

$\begin{array}{ll}\text { Inflation } & =\mathrm{f} \text { (Privatization) } \\ \text { Per Capita Income (Purchasing Power Parity) } & =\mathrm{f} \text { (Privatization) } \\ \text { Unemployment } & =\mathrm{f} \text { (Privatization) } \\ \text { GDP } & =\mathrm{f} \text { (Privatization) }\end{array}$

\section{Results}

A. GDP

\begin{tabular}{lclll}
\hline \hline \multicolumn{1}{c}{ Variable } & Coefficient & Std. Error & t-Statistic & Prob. \\
\hline \hline \multicolumn{1}{c}{ C } & 1668968. & 570572.1 & 2.925079 & 0.0104 \\
PRIV & 53.58114 & 22.18955 & 2.514702 & 0.0290 \\
\hline \hline R-squared & 0.279912 & Mean dependent var & 2497945. \\
Adjusted R-squared & 0.231906 & S.D. dependent var & 2144027. \\
S.E. of regression & 1879046. & Akaike info criterion & 31.84056 \\
Sum squared resid & $5.30 \mathrm{E}+13$ & Schwarz criterion & 31.93858 \\
Log likelihood & -268.6447 & F-statistic & 5.830784 \\
Durbin-Watson stat & 0.624350 & Prob(F-statistic) & 0.028979 \\
\hline \hline
\end{tabular}


The $2.51 \mathrm{t}$-value of GDP to Privatization is showing statistically significant relationship. $P$ value is explaining that the relationship is significant at $97 \%$ confidence interval. The privatization coefficient PRIV is 53.5811 , which shows the existence of positive relation between the two variables and further explains that by increasing the privatization by 53.58 million, (i.e. one million increase in the GDP) can be achieved. It has also been historically and statistically evident that in the case of Pakistan, privatization brings positive effects to the economy. Though the coefficient of determination (r-square) is 0.27 , still a $27 \%$ variation in GDP due to privatization is considerable.

\section{B. Inflation}

\begin{tabular}{lrlrl}
\hline \hline \multicolumn{1}{c}{ Variable } & Coefficient & Std. Error & t-Statistic & Prob. \\
\hline \hline \multicolumn{1}{c}{ C } & 9.490155 & 1.492516 & 6.358496 & 0.0000 \\
PRIV & $-4.88 \mathrm{E}-05$ & $5.80 \mathrm{E}-05$ & -0.840581 & 0.4138 \\
\hline \hline R-squared & 0.044986 & Mean dependent var & 8.735294 \\
Sum squared resid & 362.3954 & Schwarz criterion & 6.230719 \\
Log likelihood & -50.12790 & F-statistic & 0.706576 \\
Durbin-Watson stat & 0.856647 & Prob(F-statistic) & 0.413782 \\
\hline \hline
\end{tabular}

The t-stat value of Inflation to privatization is not significant, which shows that statistically no relationship between inflation and privatization exist. I tried to check this relationship by transforming my model by taking log of both variables and taking square root also. But in none of the case I found significant results. So here it can be concluded that privatization has no relationship with inflation (CPI).

\section{Unemployment}

\begin{tabular}{lrlll}
\hline \hline \multicolumn{1}{c}{ Variable } & Coefficient & Std. Error & t-Statistic & Prob. \\
\hline \hline \multicolumn{1}{c}{ C } & 6.977074 & 0.294992 & 23.65175 & 0.0000 \\
PRIV3 & 0.066742 & 0.027916 & 2.390845 & 0.0295 \\
\hline \hline R-squared & 0.263221 & Mean dependent var & 7.600000 \\
Adjusted R-squared & 0.217172 & S.D. dependent var & 0.663325 \\
S.E. of regression & 0.586894 & Akaike info criterion & 1.876493 \\
Sum squared resid & 5.511109 & Schwarz criterion & 1.975424 \\
Log likelihood & -14.88844 & F-statistic & 5.716139 \\
Durbin-Watson stat & 1.411647 & Prob(F-statistic) & 0.029451 \\
\hline \hline
\end{tabular}

In order to remove specification biasness I have taken the square root of the privatization data. The P-value is depicting a statistically significant relationship at almost $97 \%$ confidence interval. The coefficient of privatization is showing a positive relationship between employment and privatization, which means privatization process may be a source of unemployment. 
Statistical result justifies the previous studies, which reveals that Privatization somehow affects the employment level negatively as the Privatized firm tends to do so to increase their efficiency

\section{Per Capita Income (Purchasing Power Parity)}

\begin{tabular}{lrlll}
\hline \hline \multicolumn{1}{c}{ Variable } & Coefficient & Std. Error & t-Statistic & Prob. \\
\hline \hline \multicolumn{1}{c}{ C } & 12004.07 & 3678.188 & 3.263583 & 0.0052 \\
PRIV & 0.330657 & 0.143045 & 2.311563 & 0.0354 \\
\hline \hline R-squared & 0.262657 & Mean dependent var & 17119.81 \\
Adjusted R-squared & 0.213501 & S.D. dependent var & 13658.77 \\
S.E. of regression & 12113.25 & Akaike info criterion & 21.75212 \\
Sum squared resid & $2.20 \mathrm{E}+09$ & Schwarz criterion & 21.85014 \\
Log likelihood & -182.8930 & F-statistic & 5.343323 \\
Durbin-Watson stat & 0.625511 & Prob(F-statistic) & 0.035423 \\
\hline \hline
\end{tabular}

The $2.31 \mathrm{t}$-value of Per Capita Income to Privatization is showing statistically significant relationship. $P$ value is explaining that the relationship is significant at almost $96 \%$ confidence interval. The privatization coefficient PRIV is showing the existence of positive relation between the two variables and further explains that by increasing the privatization by 0.33065 million (Rs), a 0.001 thousand (Rs) increase in the Per Capita Income may be achieved. Again the coefficient of determination ( $r$-square) is 0.26 , but still a $26 \%$ variation in Per Capita Income due to privatization is considerable.

\section{Conclusion}

This study concludes that privatization does not directly effect Inflation but it does effect GDP, Per Capita Income (Purchasing Power Parity) positively and employment negatively. It means that level of inflation, variable of our particular interest, is not being affected by privatization. So by seeing the empirical results of "Privatization vs. Inflation" this myth can be debunked that privatization is one important cause of inflation.

The second variable if our prime interest is "Per Capita Income (PPP)" has shown positive relationship with privatization. It means by accelerating privatization in a smooth way Per Capita Income of the individuals may be increased.

One of the most offered reason against privatization can be validated by seeing its statistical relationship with unemployment. Data results have confirmed that privatization has a negative effect on employment and may be a source of unemployment. But these results are in accordance with previous studies.

Results of other variables (i.e. GDP) authenticate the previous studies which revealed that privatization effects GDP positively in most of the cases. From the result it can be concluded that unlike conventional myth, the acceleration of privatization can accelerate the growth. 
As a conclusive remark we will recommend that government should go for the privatization. In the short run, it will make fiscal balances positive not only by reducing the amount being injected to SOEs in order to keep them operational but also can increase the government revenues in shape privatization proceeds. In the long run, it will accelerate the GDP and Per Capita Income (PPP). 


\section{References}

Roland, Gérard and Stiglitz, Joseph., (Jun 16, 2008) Privatization: Successes and Failures, New York (Initiative for Policy Dialogue).

Elliott D. Sclar and Richard C. Leone (Dec 2001) You Don't Always Get What You Pay for: The Economics of Privatization (Century Foundation Books, New York (Cornell)

Tim Buthe and Walter Mattli (Mar 20, 2011) The New Global Rulers: The Privatization of Regulation in the World Economy.

Economic Survey of Pakistan (2008-09 \& 2009-10)

Megginson, William L. 2005. The Financial Economics of Privatization (New. York: Oxford University Press)

John D. Donahue (1991) "The Privatization Decision: Public Ends, Private Means" Basic Books.

Harper, Joel T. (2001) "Effect of privatization on Economic Growth"

Shleifer and Vishny "Efficiency of Privatized firms"

Elizabeth Alexander, Alex Friedman, Christian Parenti and Allison Campbell (Jul 22, 2008) CAPITALIST PUNISHMENT: Prison Privatization and Human Rights.

Stiglitz, Joseph (2002) "Globalization and its Discontents" New York: W.W. Norton. Iram A Khan (2010) "Privatization's impact on Growth and unemployment: A Case Study of Pakistan"

Lewis D. Solomon (Nov 10, 2009) The Promise and Perils of Infrastructure Privatization: The Macquarie Model

Zaidi, S. Akbar. (2005) Issues in Pakistan's Economy. Karachi: Oxford University Press.

Ansari, Naeem, \& Zubairi "Financial Management in Pakistan"

S.R. Khan, (1997) Fifty Years of. Pakistan's Economic Development, Oxford University Press, Islamabad, 